Full length article

\title{
Can stability of foreign aid agreement reduce global income inequality?
}

\author{
Maria Berrittella \\ Università degli Studi di Palermo, Dipartimento di Scienze Economiche, Aziendali e Statistiche, Viale delle Scienze, 90128 Palermo, Italy
}

\section{A R T I C L E I N F O}

\section{Article history:}

Received 11 March 2016

Available online 16 March 2017

\section{JEL classification:}

D58

F35

H77

Keywords:

Computable general equilibrium model

Foreign aid

Global income inequality

Stability

\begin{abstract}
A B S T R A C T
$\overline{\text { Global initiatives on debt relief call for increasing foreign aid assistance to alleviate income }}$ inequality. But the potential gains from foreign aid policy coordination may be limited by the willing participation of diverse and self-interested donor countries. If stability of the foreign aid agreement does not occur, then aid effectiveness fails. Thus, the aim of this paper is to investigate the effects of the stability of foreign aid agreement on income redistribution amongst countries. The findings show that stability has positive effects on income mobility from the rich to the poorest countries reducing global income inequality.

(C) 2017 Economic Society of Australia, Queensland. Published by Elsevier B.V. All rights
\end{abstract} reserved.

\section{Introduction}

Global initiatives call for increasing foreign aid assistance to alleviate income inequality. The Organization for Economic Cooperation and Development (OECD) reports continuing growth in Official Development Aid (ODA). In fact, during 1960-2013, total ODA disbursements has substantially increased and at least 3.5 trillion dollars have been given as foreign aid from rich to poor countries. The largest donors result to be the United States, France, Germany and the United Kingdom. Furthermore, Qian (2015) reports that 24\% (on average) of ODA during 2006-2012 for all donors countries was not transferred to the recipient countries, but the aid money was instead spent on activities in donor countries, mainly for debt relief, administrative costs and expenditure on refugees.

The literature on foreign aid is really rich, but the theoretical and empirical studies report quite different views on the relationship between foreign aid and income. On the one hand, there exist studies supporting the positive effects of the foreign aid. The endogenous growth model developed by Rosenstein-Rodan (1943) shows that foreign aid provides investment capital, which would generate income and raise up the return to capital and promote economic growth. Dalgaard and Hansen (2001) show that there is a linear effect in the aid-income growth relationship due to diminishing returns to foreign aid. Burnside and Dollar (2000), Dollar and Kraay (2001) and Collier and Dollar (2002) suggest that foreign aid coupled with good policies, such as private property rights, fiscal discipline, macroeconomic stability and open to trade, increase the income of the poor countries. On the other hand, there are studies that show the failure of foreign aid to alleviate income inequality. Bauer (1975) defines foreign aid as "a transfer of resources from the taxpayer of a donor country to the government of a recipient country". Furthermore, he argues that as donors do not know which investments are appropriate for the recipient country, the transfer of foreign aid destroys economic incentives, leads to misallocation of scarce resources and undermines economic growth. Based on both the history and the evidence on foreign aid, Easterly (2003) shares similar view as

E-mail address: maria.berrittella@unipa.it. 
Bauer (1975) questioning about the alternative definition of "aid" "good policy" and "growth" to illustrate the complex relationship between foreign aid and income and the high possibility of failure. Doucouliagos and Paldam (2008) conclude that the aid literature has failed to prove that the effect of aid on growth is statistically larger than zero. The existing empirical evidence on foreign aid also fails to prove an inequality decreasing effect on income distribution (i.e. Calderón et al., 2006; Herzer and Nunnenkamp, 2012). The failure of foreign aid may due to various factors, such as poor governance of foreign aid funding, inefficient and unfair aid distribution amongst the recipient countries, conditional requirements of donor countries, political instability in the recipient countries (Dollar and Kraay, 2001; Inanga, 2008; Younas, 2008; Brück and Xu, 2012; Kalyvitis et al., 2012a; Kalyvitis and Vlachaki, 2012b; Raschky and Schwindt, 2012). Furthermore, there are some studies that have found ambiguous or mixed relationship between foreign aid and growth in the poor countries (Inanga and Mandah, 2008; Werker et al., 2009; Ekanayake and Chatrna, 2010). Holder (2004) argues that the relationship between foreign aid and growth turns out to be an inverted-U shaped under reasonable policy assumption, which is an Aid Laffer Curve. Positive relationship between foreign aid and growth is located in the upward sloped side of the Aid Laffer Curve, while the negative relationship is located at the downward sloped side of the Aid Laffer Curve. Similarly, in a sample of 42 aid recipients covering the period 1970-2000, Kalyvitis and Vlachaki (2012b) find that there is a threshold level of aid, above which the growth impact of aid becomes positive. The different views on the relationship between foreign aid and income may related to the problems of data measurement and identification due to the heterogeneous nature of aid (Qian, 2015).

From the analysis of this literature one aspect emerges, that is, the stability of foreign aid agreement has not been still now appropriately faced. The aim of foreign aid transfer may deviate from its original outcome of interest due to various factors in each stage (creation, implementation, distribution and monitoring system) generating instability of the foreign aid agreement. Generally, as the foreign aid increases the income of the recipient country and decreases that of the donors, the free-rider problem arises due to the presence of multiple donors who are motivated by self-interest. Thus, the mere coordination of aid, such as general budget supports, will not automatically guarantee the suboptimality of aid provisions (Rahman and Sawad, 2012). Berrittella (2011) shows that if the gains from cooperation are largest, there are countries that have incentive to defect from the foreign aid agreement. This suggests that the effects of the foreign aid agreement may be biased if stability is not taken into account. In fact, ex-ante, the initial aid distribution in the agreement is established to obtain defined outcome (i.e. economic growth, population well-being, institutional development, income redistribution) in the recipient countries under the condition that no donor country defects, if this condition does not occur, ex-post, aid effectiveness fails. Stability of the foreign aid agreement guarantees the aid effectiveness, both ex-ante and ex-post. In this context, first of all, one question that merits to be faced is if stability of foreign aid agreement can increase the income mobility from the rich to the poorest countries. Using a multi-country computable general equilibrium model (CGE), the aim of this paper is to investigate the relationship between stability and global income inequality. The main findings show that the stability of the foreign aid agreement has positive effects on income redistribution from the donor to the recipient countries and global income inequality decreases. As no country has incentive to free-ride, the income mobility from the donor to the recipient countries will be effective.

\section{Modeling framework}

In order to assess the systematic general-equilibrium effects of foreign aid, a multi-country CGE model, labeled AIDCGEM (Berrittella and Zhang, 2014), has been applied, which is a modified version of the standard GTAP model (Hertel, 1997).

A CGE model describes an economy in equilibrium with endogenously determined relative prices and quantities guaranteeing theoretical and accounting consistency. Differently to partial equilibrium models, CGE models allow of evaluating the effects of exogenous shift of policy variables on macroeconomic indicators (i.e. GDP, trade balance and welfare), taking into account the interdependence among all markets and regions. A CGE model builds on a closed accounting system of simultaneous equations representing market equilibrium: equality between supply and demand in each market in the economy. As compared to other methods, one of the advantages is that CGE models can provide concrete measures of changes in welfare due to policy change. This is particularly important for the aim of this paper, because the CGE model allows of answering to questions on who are the winners and losers from changing foreign aid policies, providing policy makers with a better understanding of the possible social results of the income redistribution from the rich to the poorest countries. An assessment of the usefulness of CGE models for policy analysis can be found in Borges (1986), Shoven and Whalley (1992) and Piermartini and The (2005). Furthermore, the CGE approach has been extensively used for the analysis of foreign aid (i.e. Nugent, 1988; Nechyba, 1996; Arndt and Tarp, 2001; Clausen and Schürenberg-Frosch, 2012).

AIDGEM is a comparative static, multi-commodity, multi-region model with the assumptions of perfect competition, market equilibrium and open economy.

On the consumption side, the economy is modeled by a representative household in each region $r$, whose Cobb-Douglas utility function allocates expenditures between private consumption $(C)$, government consumption $(G)$ and savings expenditure $(S)$ as follows:

$$
U_{r}=C_{r}^{\alpha_{C, r}} G_{r}^{\alpha_{G, r}} S_{r}^{\alpha_{S, r}}
$$

with $\alpha_{C, r}, \alpha_{G, r}$ and $\alpha_{S, r}$ income shares and $\alpha_{C, r}+\alpha_{G, r}+\alpha_{S, r}=1$.

The constrained optimizing behavior of the household in region $r$ for private consumption is represented by a nonhomothetic Constant Difference of Elasticity (CDE) expenditure function for the set of goods and services. A Cobb-Douglas 
sub-utility function is employed for government spending. In this case the expenditure shares are constant across all commodities. Private and government consumption are split in a series of alternative composite Armington aggregates (Armington, 1969).

On the production side, the producers receive payments for selling consumption goods to the private households and the government, intermediate inputs to other producers and investment goods to the savings sector. Under the zero profit assumption, these revenues must be precisely exhausted on expenditures for intermediate inputs and primary factors of production. The nested production technology exhibits constant returns to scale and every sector produces a single output. The technology is simplified by employing the Constant Elasticity of Substitution (CES) functional form:

$$
y_{i, r}=\left(\sum_{j=1}^{n} \theta_{j} x_{j, r}^{1-\frac{1}{\sigma}}\right)^{\frac{\sigma}{\sigma-1}}
$$

where, in region $r, y_{i, r}$ is the production of the good $i, x_{j, r}$ is the input $j, \theta_{j}$ is a non-negative parameter, with $\sum_{j=1}^{n} \theta_{j}=1$, and $\sigma$ is the elasticity of substitution.

Both intermediate and final products from different regions are considered to be imperfectly substitutable with each other (Armington, 1969). All factor inputs (land, labor, capital and natural resources) are assumed to be fully employed and immobile across regions. Capital and labor are perfectly mobile across sectors and, hence, they earn the same market return regardless of where they are employed; land and natural resources are sluggish to adjust and their returns may differ across sectors.

Savings are exhausted on investment and capital markets are assumed to be in equilibrium only at the global level. If savings exceed investments for one country, then it has a trade surplus; otherwise, it has a trade deficit. A hypothetical world bank collects savings from all regions and allocates investments so as to achieve equality of changes in expected future rates of return:

$$
\Delta \eta_{r}=\Delta \eta
$$

where $\Delta \eta_{r}$ and $\Delta \eta$ are the percentage change, respectively, in region's rate of return and global rate of return.

Every economy includes government interventions. Private households and the government not only spend their available income on consumption goods, but also pay taxes to the regional household. In the case of the government, taxes consist of consumption taxes on commodities. In the case of private household, taxes consist of consumption taxes and income tax net of subsidies. The firms have to pay taxes to the regional household. These value flows represent taxes on intermediate inputs and production taxes net of subsidies. Also trade generated tax revenues and subsidy expenditures are included in the GTAP model. All taxes levied in the economy always accrue to the regional household.

The foreign aid is inserted into the equation computing the national income as the total value of all domestic primary resources. Thus, let $\mathrm{AID}_{r}$ be the income transfer in region $r$, the regional income is equal to:

$$
Y_{r}=\sum_{i=1}^{n} P_{i, r} E_{i, r}+T_{r}+A I D_{r}
$$

where $E_{i, r}$ is the endowment $i$ and $P_{i, r}$ is the market price of the endowment $i, T_{r}$ are the tax revenues. The income transfer will increase (decrease) the regional income of the recipient (donor) country. To be consistent with general equilibrium conditions, the algebraic sum of all income transfers introduced in the model equations must be zero. This ensures that the redistribution of income is globally neutral.

\subsection{Data calibration}

The AIDCGEM model is calibrated for the year 2001 using the GTAP data base, version 6, which is a cross-section data of international trade flows and national input-output tables. All the information in the data base is reported in values converted to US dollars. The behavioral parameters utilized in the GTAP model are described in Dimaranan (2006). They define the magnitude of behavioral responses to changes in relative prices. In particular, there are four sets of behavioral parameters in GTAP data base: (i) elasticities of substitution, in both consumption and production; (ii) transformation elasticities, that determine the degree of mobility of primary factors across sectors; (iii) the flexibilities of regional investment allocation; (iv) consumer demand elasticities.

The GTAP data base includes 87 regions and 57 commodities. For this analysis, the regions are aggregated from 87 regions to 16 regions. The regional aggregation has been selected primarily based on importance in the world production, consumption, international trade, economic development and geographic location. Thus, the regional aggregation includes five donor countries and eleven recipient countries (Table 1 ).

As the GTAP 6 data base contains data for 2001, but the aid policy is designed for the year 2010, the methodology described in Arndt et al. (1997) has been applied to provide a status quo projection of the global economy in the selected year. The approach is based on a two-stage procedure. Firstly, "pseudo-calibrations" have been generated from 2001 to 2010 by calibrating the technical parameters related to population growth, capital and labour stock change, labour and land 
Table 1

Regional aggregation.

Source: Author's modelling aggregation based on GTAP v.6 data base.

\begin{tabular}{|c|c|c|}
\hline Acronym & Region & Type \\
\hline USA & United States & Donor \\
\hline CAN & Canada & Donor \\
\hline WEU & $\begin{array}{l}\text { Western Europe (Austria, Belgium, Denmark, Finland, France, Germany, Greece, Iceland, Ireland, Italy, } \\
\text { Liechtenstein, Luxembourg, the Netherlands, Norway, Portugal, Spain, Sweden, Switzerland, the United } \\
\text { Kingdom) }\end{array}$ & Donor \\
\hline JPK & Japan and South Korea & Donor \\
\hline ANZ & Australia, New Zealand and Oceania & Donor \\
\hline EEU & $\begin{array}{l}\text { Eastern Europe (Bulgaria, Cyprus, Czech Republic, Estonia, Hungary, Latvia, Lithuania, Malta, Poland, Romania, } \\
\text { Slovakia, Slovenia) }\end{array}$ & Recipient \\
\hline FSU & Former Soviet Union & Recipient \\
\hline MDE & Middle East (Turkey, Rest of Middle East) & Recipient \\
\hline CAM & Central America (Mexico, Central America, Caribbean) & Recipient \\
\hline SAM & $\begin{array}{l}\text { South America (Colombia, Perù, Venezuela, Rest of Andean Pact, Argentina, Brazil, Chile, Uruguay, Rest of } \\
\text { South America) }\end{array}$ & Recipient \\
\hline SAS & South Asia (Bangladesh, India, Sri Lanka, Rest of South Asia) & Recipient \\
\hline SEA & Southeast Asia (Taiwan, Indonesia, Malaysia, Philippines, Singapore, Thailand, Vietnam) & Recipient \\
\hline CHI & China (China, Hong Kong) & Recipient \\
\hline NAF & North Africa (Morocco, Rest of North Africa) & Recipient \\
\hline SSA & $\begin{array}{l}\text { Sub-Saharan Africa (Botswana, Rest of SACU, Malawi, Mozambique, Tanzania, Zambia, Zimbabwe, Other } \\
\text { Southern Africa, Uganda, Rest of Sub-Saharan Africa) }\end{array}$ & Recipient \\
\hline ROW & Rest of the world & Recipient \\
\hline
\end{tabular}

productivity change, so that to achieve growth in regional GDP consistent with the World Bank projections, as showed also in Berrittella and Zhang (2014). The resulting scenario in this first stage is called "baseline". Subsequently, conventional comparative analysis is conducted in the policy design simulations.

\section{Stability conditions}

A multi-country agreement is stable if each country gains, in terms of welfare, from joining it. The gains from the agreement for country $i\left(G f C^{i}\right)$, with $i=1, \ldots, n$, are the difference between the welfare if there is the agreement, $W_{C}^{i}$ and the welfare if there is no agreement, $W_{N C}^{i}$, that is:

$$
G f C^{i}=W_{C}^{i}-W_{n c}^{i} .
$$

Let $T^{i}$ be the minimum non-negative payment to country $i$ necessary to make foreign aid agreement more attractive than no agreement (called also side-payment), we have:

$$
T^{i}=\max \left\{0, W_{n c}^{i}-W_{c}^{i}\right\} .
$$

The side-payment is a measure of the difficulty that will be encountered in reaching the agreement. The difficulty to agreement refers to the incentive to do ex-ante negotiations, and not to the gains that will be sustained with exante negotiations by the countries. Clearly, $T^{i}$ may be zero for all $i$ (i.e. in the extreme case, if the countries would be homogeneous), but it cannot be positive for all $i$, otherwise, the world welfare from foreign aid agreement would be less than the world welfare if there is no agreement.

The willingness to pay of country $i, W T P^{i}$, is equal to the positive gains from the agreement, that is

$$
W T P^{i}=\max \left\{0, W_{c}^{i}-W_{n c}^{i}\right\} .
$$

An agreement is stable if the sum of the willingness to pay is greater than the sum of the side-payments, that is if

$$
\sum_{j} W T P^{j} \geq \sum_{i} T^{i} \quad \text { with } j+i=n .
$$

In other words, let us define the agreement rate, $s$, as follows:

$$
s=\frac{\sum_{j} W T P^{j}}{\sum_{i} T^{i}}
$$

if $s \geq 1$ then the foreign aid agreement is stable. 
Table 2

Foreign aid distribution: first step.

Source: Author's calculation.

\begin{tabular}{lll}
\hline Region & Income transfer & $\Delta W_{r}(M \ln$ US \$) \\
\hline Donor & & \\
\hline United States & -26076 & -32485 \\
Canada & -5277 & -6293 \\
Western Europe & -42585 & -57010 \\
Japan & -10515 & -13393 \\
Australia, New Zealand \& Oceania & -3832 & -4560 \\
\hline Recipient & & \\
\hline Eastern Europe & 3159 & 4483 \\
Former Soviet Union & 1435 & 1833 \\
Middle East & 2588 & 4430 \\
Central America & 6238 & 7657 \\
South America & 2915 & 3999 \\
South Asia & 14722 & 16831 \\
Southeast Asia & 5696 & 6615 \\
China & 1791 & 1936 \\
North Africa & 1666 & 2299 \\
Sub-Saharan Africa & 25742 & 32005 \\
Rest of the World & 22333 & 28746 \\
\hline
\end{tabular}

\section{Policy design and results}

The procedure to calculate the optimal foreign aid distribution includes two steps. Firstly, the simulation of the initial aid distribution, which will give the welfare change for any country $r, \Delta W_{r}$. If welfare change is positive for country $r$, then country $r$ has incentive to participate to the foreign aid agreement both ex-ante, in terms of side-payments, and ex-post in terms of gains from cooperation. The opposite effects occur if welfare change is negative. Furthermore, if the stability condition in Eq. (8) occurs (that is: $s \geq 1$ ) then no country has incentive to defect from the agreement. Otherwise, the initial foreign aid distribution must be modified to guarantee the stability condition in Eq. (8). Secondly, given the initial aid transfer for country $r$, the associated endogenous welfare change for country $r$ is recalculated such that the sum of welfare changes is equal to zero, as follows:

$$
\Delta \tilde{W}_{r}=\Delta W_{r}-\sum_{r} \Delta W_{r} \frac{\left|\Delta W_{r}\right|}{\sum_{r}\left|\Delta W_{r}\right|} .
$$

The values of welfare change, calculated in Eq. (10), are exogenously simulated and this simulation will give the endogenous foreign aid distribution.

This two-step procedure allows of identifying the aid distribution that satisfies the stability conditions given the initial aid allocation.

Tables 2 and 3 report the simulation results of this two-step procedure. Table 2 identifies the initial aid distribution in terms of income transfer, negative for the donor countries and positive for the recipient countries. Data on the initial foreign aid distribution is extracted from the OECD STAT database (OECD, 2012) and World Bank data set (World Bank, 2012), and the standard measure of aid is used, which corresponds to the Net Official Development Assistance. The largest donors are the European countries (mainly France, Germany and the United Kingdom) and the United States, contributing, respectively, by $50 \%$ and $30 \%$. The main recipients are the Sub-Saharan African countries, that result to have received almost $30 \%$ of the total amount of foreign aid. The simulation of the income transfer related to the foreign aid increases welfare of the recipients and decreases that of the donors.

Furthermore, Table 3 reports the welfare change for country $r$ such that the sum of welfare changes is equal to zero. These values are exogenously simulated in the second step that will give the endogenous foreign aid distribution. Stability requires an increase of the foreign aid for the donor countries, except for Japan. The donors with the lowest initial income transfer (Canada, Australia New Zealand and Oceania) have to increase the foreign aid more than the other donors. Furthermore, stability requires a redistribution of the foreign aid amongst the recipient countries, with a substantial increase for the Middle East and South America. Foreign aid redistribution implies that the recipients with the highest initial income transfer (such as the Sub-Saharan African countries) will have a decrease in their income transfer. Many of the recipient countries will receive an increase in their income transfer due to the foreign aid redistribution.

The aid effects on income per capita are negative for the donor countries and positive for the recipient countries. This means that there is an income redistribution from the rich to the poor countries. In particular, the donors with the lowest income transfer yield the highest negative change in income per capita. For the recipient countries, the results suggest a U-inverted curve in the relationship between foreign aid distribution and change in income per capita. If on the one hand, the recipients that receive the highest income transfer have also the highest change in income per capita, for example Rest 
Table 3

Foreign aid distribution: second step.

Source: Author's calculation.

\begin{tabular}{lllc}
\hline Region & $\Delta \tilde{W}_{r}(M \ln$ US \$) & Aid distribution (\%) & $\begin{array}{c}\text { Income per capita } \\
(\%)^{\mathrm{a}}\end{array}$ \\
\hline Donor & & & $(\%)^{\mathrm{a}}$ \\
\hline United States & & & -0.694 \\
Canada & -32065 & -1.153 & 0.002 \\
Western Europe & -6211 & 0.063 & 0.010 \\
Japan & -56273 & 0.023 & -0.800 \\
Australia, New Zealand \& Oceania & -13219 & -0.594 & -0.459 \\
\hline Recipient & -4501 & 0.391 & -1.299 \\
\hline Eastern Europe & & & 0.004 \\
Former Soviet Union & 4541 & 0.151 & 0.013 \\
Middle East & 1857 & 0.625 & 0.455 \\
Central America & 4487 & 0.869 & 0.018 \\
South America & 7756 & -0.021 & -0.001 \\
South Asia & 4051 & 0.968 & 0.004 \\
Southeast Asia & 17049 & -0.115 & 0.018 \\
China & 6701 & -0.014 & -0.003 \\
North Africa & 1961 & 0.407 & 0.389 \\
Sub-Saharan Africa & 2328 & 0.160 & 4.576 \\
Rest of the World & 32419 & -0.122 & 0.605 \\
\hline
\end{tabular}

${ }^{a}$ Change with respect to the initial aid distribution (no stability).

${ }^{\mathrm{b}}$ Change with respect to the baseline scenario.

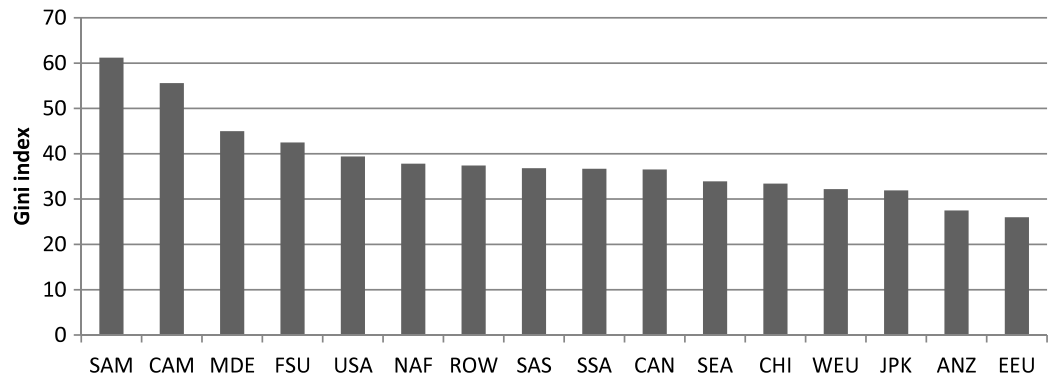

Fig. 1. Gini index

Source: Author's calculation from UNU-WIDER (2005) and World Bank (2012).

of the World and Sub-Saharan Africa. On the other hand, we have that the recipients with the lowest income transfer not always have the lowest change in income per capita, for example, North Africa. The comparison with "no stability" scenario, in terms of income per capita, shows that stability enforces the income redistribution.

The income mobility from the rich to the poorest countries is also supported in terms of global income inequality (GII) index calculated as in Milanovic (2006):

$$
G I I=\sum_{i=1}^{n} G_{i} p_{i} \pi_{i}+\frac{1}{\mu} \sum_{i}^{n} \sum_{j>1}^{n}\left(y_{j}-y_{i}\right) p_{i} p_{j}
$$

where $y_{i}$ is the per-capita income of $i$ th country, $p_{i}$ is the population share of $i$ th country in total world population, $\pi_{i}$ is the share of $i$ th country in total global income, $\mu$ is the income mean, $n$ is the number of countries and $G_{i}$ is the Gini coefficient of national income distribution.

Data on Gini coefficient of national income distribution $\left(G_{i}\right)$ come from the World Income Inequality Database (WIID) compiled by UNU-WIDER (2005) and the World Bank data set (World Bank, 2012), which contains a comprehensive collection of within country inequality data from several thousand underlying statistical surveys and is a very broad collection of national income distributions data. Fig. 1 shows the income inequality per country. For each country, the most recent data on Gini coefficient has been selected over the period 2000-2010. The GII index decreases from 67.73 in the baseline equilibrium to 67.04 in the stability scenario allowing income mobility from the rich to the poorest countries.

\section{Concluding remarks}

As the stability of the foreign aid agreement is a critical challenge for the success of aid assistance, the aim of this paper has been to investigate if stability of foreign aid agreement promotes income redistribution from the donor to the recipient 
countries. The main findings show that there is a positive effect of stability of foreign aid agreement on the income mobility from the rich to the poorest countries.

If the foreign aid distribution occurs on the basis of the stability conditions, then no country has incentive to free-ride and the income redistribution will be effective. This suggests that policy-makers must identify ex-ante the aid distribution that satisfies the stability conditions in order to avoid the failure of foreign aid.

The simulation analysis and results of this paper call for further research that investigates the relationship between stability of foreign aid agreement and income inequality; in particular, research on the design of global transfers that satisfy the requirement that income inequality decreases in both donor and recipient countries; application of alternative methodologies to the CGE modelling framework that take into account the problems of measurement and identification due to the heterogenous nature of foreign aid.

\section{References}

Armington, P.A., 1969. A theory of demand for products distinguished by place of production. IMF Staff Pap. 16, 159-178.

Arndt, C., Hertel, T., Dimaranan, B., Huff, K., McDougall, R., 1997. China in 2005: Implications for the Rest of the World. GTAP working paper. Centre of Global Trade Analysis, Purdue University.

Arndt, C., Tarp, F., 2001. Who gets the goods? A general equilibrium perspective on food aid in mozambique. Food Policy 26, 107-119.

Bauer, P.T., 1975. N.H. Stern on substance and method in development economics. J. Dev. Econ. (2), 387-405.

Berrittella, M., 2011. Stability of foreign aid agreement: A general equilibrium experimental design. Empir. Econ. Lett. 10 (3), 281-288.

Berrittella, M., Zhang, J., 2014. A global perspective on effectiveness of aid for trade. Open Econ. Rev. http://dx.doi.org/10.1007/s11079-013-9278-4.

Borges, A., 1986. Applied general equilibrium models: An assessment of their usefulness for policy analysis. OECD Econ. Stud. 7, 7-43.

Brück, T., Xu, G., 2012. Who gives aid to whom and when? Aid accelerations, shocks and policies. Eur. J. Polit. Econ. 28 (4), 593-606.

Burnside, C., Dollar, D., 2000. Aid, policies, and growth. Amer. Econ. Rev. 90 (4), 847-868.

Calderón, M.C., Chong, A., Gradstein, M., 2006. Foreign aid, income inequality and poverty. Inter-American Development Bank Working Paper No. 547.

Clausen, V., Schürenberg-Frosch, H., 2012. Aid, spending strategies and productivity effects: A multi-sectoral CGE analysis for Zambia. Econ. Modell. 29 (6), 2254-2268.

Collier, P., Dollar, D., 2002. Aid allocation and poverty reduction. Eur. Econ. Rev. 45, 1470-1500.

Dalgaard, C., Hansen, H., 2001. Aid, growth and good policies. J. Dev. Stud. 37, 17-41.

Dimaranan, B.V., 2006. Global Trade, Assistance and Application: The GTAP 6 Data Base. GTAP working paper. Center for Global Trade Analysis, Purdue University.

Dollar, D., Kraay, A., 2001. Growth is good for the poor. J. Econ. Growth 7 (3), 195-225.

Doucouliagos, H., Paldam, M., 2008. Aid effectiveness on growth: A meta study. Eur. J. Polit. Econ. 24, 1-24

Easterly, W., 2003. Can foreign aid buy growth? J. Econ. Perspect. 17, 23-48.

Ekanayake, E.M., Chatrna, D., 2010. The effect of foreign aid on economic growth in developing countries. J. Int. Bus. Cult. Stud. 3, 1-13.

Hertel, T.W., 1997. Global Trade Analysis Modeling and Applications. Cambridge University Press, Cambridge, UK.

Herzer, D., Nunnenkamp, P., 2012. The effect of foreign aid on income inequality: Evidence from panel cointegration. Struct. Change Econ. Dyn. 23 (3), $245-255$

Holder, R., 2004. Redistribution to Rent Seekers, Foreign Aid and Economic Growth. Working Paper, Universität Bern Volkswirtschaftliches Institut, Switzerland.

Inanga, Eno L., Mandah, E., 2008. Foreign aid finance and economic development: the case of two foreign aid financing agencies in zambia. Int. Res. J. Financ. Econ. 14, 322-358,

Kalyvitis, S., Stengos, T., Vlachaki, I., 2012a. Are aid flows excessive or insufficient? Estimating the growth impact of aid in Threshold regressions. Scott. J. Polit. Econ. 59, 298-315.

Kalyvitis, S., Vlachaki, I., 2012b. When does more aid imply less democracy? An empirical examination. Eur. J. Polit. Econ. 28, $132-146$.

Milanovic, B., 2006. Global income inequality: what is and why it matters? DESA Working Paper No. 26.

Nechyba, T., 1996. A computable general equilibrium model of intergovernmental aid. J. Public Econ. 62 (3), 363-397.

Nugent, J.B., 1988. Foreign aid, economic development and income distribution: Some inferences from a CGE model for Egypt. In: Sengupta, J., Kadekodi, G. (Eds.), Econometrics of Planning and Efficiency. Kluwer Academic Publishers, Dordrecht, pp. 63-90.

OECD, 2012. Aid Statistics. (available at: http://www.oecd.org/dac/aidstatistics/).

Piermartini, R., The, R., 2005. Demystifying modelling methods for trade policy. Discussion Paper No. 10. Economic Research and Statistics Division, World Trade Organization, Geneva.

Qian, N., 2015. Making progress on foreign aid. Annu. Rev. Econ. 7, 277-308.

Rahman, A., Sawad, Y., 2012. Can donor coordination solve the aid proliferation problem? Econom. Lett. 116 (3), 609-612.

Raschky, P.A., Schwindt, M., 2012. On the channel and type of aid: The case of international disaster assistance. Eur. J. Polit. Econ. 28 (1), $119-131$.

Rosenstein-Rodan, P.N., 1943. Problems of industralisation of Eastern and South-Eastern Europe. Econ. J. 53, 202-211.

Shoven, J.B., Whalley, J., 1992. Applying General Equilibrium. Ed.. Cambridge University Press, UK.

UNU-WIDER, 2005. World Income Inequality Database, Version 2.0a. Helsinki, Finland, United Nations Universitys World Institute for Development Economics Research.

Werker, E., Faisal, A.Z., Cohen, C., 2009. How is foreign aid spent? Evidence from a natural experiment. Amer. Econ. J.: Macroecon. 1 (2), $225-244$.

World Bank, 2012. World Development Indicators (available at http://data.worldbank.org/data-catalog/world-development-indicators).

Younas, J., 2008. Motivation for bilateral aid allocation: Altruism or trade benefits. Eur. J. Polit. Econ. 24 (3), 661-674. 